\title{
The Experience of a Football Championship Subdivision
}

\author{
Student-Athlete
}

\author{
Megan R. Turk \\ University of Arkansas
}

Sarah E. Stokowski

University of Arkansas

Amber M. Shipherd

Texas A\&M University - Kingsville

\section{Bo Li}

\section{Saint Ambrose University}

\begin{abstract}
Many scholars believe that due to the intensity of college sport, student-athletes are denied a well-rounded experience. Although previous research has focused on the educational experiences of the general student-athlete population, few studies have focused on the culture that constructs the overall student-athlete experience. The authors utilized Riessman's (2008) narrative methodology to reveal the genuine human experience and assist in mobilizing action for progressive social change. The data was collected via semi-structured interviews and journal entries to examine the embodied in-season experience of one athletically gifted Cuban Football Championship Subdivision (FCS) football student-athlete. Open coding revealed four major themes that are discussed: football, identity, social support, and stereotype. This study is one of the first to explore both the experience of a FCS student-athlete and shed light on a Cuban football student-athlete's experience.
\end{abstract}

Keywords: student-athlete, experience, football, minority, Football Championship Subdivision 
"I'm sorry for being late," He says trying to catch his breath. As He sits down, He takes off his blue winter hat, revealing his long, dark mane. His cheeks are pink from the cold, hiding his normally olive skin. He's wearing black Nike sweat pants, royal blue Nike shoes with a white swoosh, and a black Nike dry-fit shirt covered by his blue and black letterman's jacket. The researchers look at him and smile. One of the researchers states, "I'm just glad you're here, as I noticed you were not in class this morning." Suddenly, He looks up at us with his olive eyes and smiles, "Well, apparently I'm a lot more excited for this interview."

He is one of 175,952 student-athletes competing at a National Collegiate Athletic Association (NCAA) Division I institution and one of the 12,886 men competing in football at the Football Championship Series (FCS) level (Irick, 2015). He is also one of the $0.7 \%$ of Hispanic/Latino men playing football at a FCS institution (Irick, 2014). He holds FCS records and has received All-American honors. According to the most recent NCAA (2014b) statistics, He is playing in front of an average of 8,130 patrons at each FCS football competition. He will also live his dream, because in less than six months from this interview, He will be among the $3.7 \%$ of NCAA football student-athletes that go on to play in the National Football League (NFL) (NCAA, 2016a).

Although past studies have focused on the student-athlete experience (Gayles, 2009; Harrison et al., 2010; Harrison, Tranyowicz, Bukstein, McPherson-Botts, \& Lawrence, 2014; Papanikolaou, Nikolaidis, Patsiaouras \& Alexopoulos, 2003; Potuto \& O’Hanlon, 2007; Yopyk \& Prentice, 2005), virtually nothing is known about the experience of student-athletes that compete at the FCS level. Literature is also scarce regarding Hispanic/Latino student-athletes in general. Given his unique situation and the lack of research that focuses on the FCS, there is a need for this particular population of student-athletes to be explored. The purpose of this study is to understand the embodied experience of a FCS football student-athlete. Specifically, how does being a standout football player at a FCS institution shape His lived experience?

\section{Review of the Literature}

\section{Football Bowl Subdivision vs. Football Championship Subdivision}

Football led to the establishment of the National Collegiate Athletic Association (NCAA) and more than a century later, the game remains one of the association's most prominent sports (Crowley, 2006). However, in 1957 when the NCAA began hosting championships in selected sports, there was frustration throughout the membership (Crowley, 2006). All NCAA membership institutions were competing in the "College Division" despite institutions having disproportionate resources (Crowley, 2006). To help ensure fair competition, in 1968 the NCAA asked member institutions to identify the institutions they would like to compete against by asking members to categorize what classification they belonged to, the College Division or the University Division (Crowley, 2006).

By 1973 the NCAA was sponsoring 10 championships and post-season bowl games for members of the College Division (Crowley, 2006). Although there were two different divisions, the rules remained the same. However, at the $67^{\text {th }}$ NCAA convention, the Committee of Reorganization advocated for two distinguishing divisions (Crowley, 2006). Despite the fact that 
initial efforts to reorganize were not approved, in August 1973, the membership agreed to a new framework consisting of three divisions (Division I, II, and III).

At the time, 237 institutions decided to become Division I institutions (Crowley, 2006). Despite the vast interest regarding institutions competing at the Division I level, football was problematic. There were powerhouse institutions filling stadiums with massive budgets that did not want to share their revenue among the membership. Furthermore, of the institutions that selected Division I membership, nearly 47\% did not sponsor the sport of football (Crowley, 2006). Some institutions felt the newly formed Division I was not only too big, but also failed to meet the goals and the objectives of selected institutions that were heavily invested in football.

In 1976, 56 institutions assembled in Dallas to further separate themselves from the rest of the Division I membership in order to experience an increase in financial and competitive success. Examining stadium capacity, overall attendance, and scheduling, the 56 institutions decided to invite 78 Division I institutions into the football elite, soon to become the College Football Association (Crowley, 2006). At the 1978 NCAA Convention, a proposal was made and voted on that would essentially separate the NCAA Division I membership. Divided by an attendance rule of 17,000, the membership voted to create two Divisions I sub-divisions, Division I-A and I-AA (Crowley, 2006). College Football Classifications are still in existence; however, in the fall of 2006, Division I-A became the Football Bowl Subdivision (FBS) and Division I-AA came to be called the Football Championship Subdivision (FCS). According to the latest data available, both subdivisions (the FBS and the FCS) consist of 125 institutions (Irick, 2015). The classification is strictly based on football sponsorship. The following describes membership requirements to be considered a FBS institution.

\section{Membership requirements.}

Prior to 2014, there was one glaring difference between the two subdivisions: FBS programs strictly participated in bowl games as determinants of a national championship while FCS programs participated in the NCAA-run football championship. All other sports at respective universities are simply referred to as Division I and the subdivisions apply solely to football (NCAA.org). The NCAA Membership Requirements (2014a) state that in order to be considered a FBS institution, the following must occur: sponsor a minimum of 16 teams, schedule at least $60 \%$ of football contests against FBS member teams, play at least five regular season games against FBS opponents, average at least 15,000 in actual attendance for home games over two years, pay at least $90 \%$ of the maximum number of football scholarships over a two year period, and offer 200 scholarships or at least $\$ 4$ million to student-athletes across all athletic programs.

\section{Overall demographic.}

According to the 2015 NCAA Sport Sponsorship and Participation Rates Report (Irick, 2015), 175,952 student-athletes competed at NCAA Division I institutions - 94,200 of them male. A total of 27,873 Division I student-athletes participated in football (both at the FBS and FCS level); 125 institutions competed at the Division I FCS level and 125 institutions competed in the FBS (Irick, 2015). The number of athletes participating in football in the FCS was 12,886 and the 
average squad size was 103.1 compared to a total of 14,987 student-athletes participating in the FBS with an average squad size of 119.9 (Irick, 2015).

\section{Football ethnic demographic.}

The FCS is restricted to 63 football scholarships to be split among the 85 players receiving aid (NCAA, 2014b). In the 2013-2014 academic year, the football student-athlete demographic for all Division I FCS institutions were as follows: $46.6 \%$ Black, $42.2 \%$ White, $4.2 \%$ other, $3.9 \%$ two or more races, $2.1 \%$ Hispanic/Latino, $0.8 \%$ nonresident alien, $0.7 \%$ Native Hawaiian/Pacific Islander, 0.3\% American Indian/Alaskan Native, and 0.04\% Asian (NCAA, 2016b). The FBS ethnic demographic was extremely similar to FCS institutions: $49.3 \%$ Black, 38.7\% White, 3.8\% two or more races, $2.7 \%$ other, $2.5 \%$ Hispanic/Latino, $1.8 \%$ Native Hawaiian/Pacific Islander, 0.5\% Asian, $0.5 \%$ nonresident alien, and 0.4\% American Indian/Alaskan Native (NCAA, 2016b). It is important to note that the differences between FCS and FBS ethnic demographics are miniscule and studying FCS student-athletes, especially minorities, is important.

\section{Revenues and expenses.}

According to Fulks (2015) who compiled the NCAA's Division I Intercollegiate Athletics Program Report, the median revenue for both FBS (6.1\%) and FCS (9.1\%) institutions saw an increase between 2013 and 2014. However, both subdivisions also saw an increase in expenses by an average of 3.7\% (Fulks, 2015). Ticket sales, alumni contributions, and NCAA and conference distributions constitute for the majority of revenues at both FBS and FCS institutions. At the FCS level, guarantees account for $12 \%$ of generated revenues. Both subdivisions reported the majority of their expenses coming from (a) scholarships and (b) salaries (Fulks, 2015). No FCS institutions reported positive net revenues for 2014; 24 FBS institutions reported positive net revenues (Fulks, 2015). It is important to note the significant discrepancy is from the BCS level to the FCS level. The largest revenue reported by a FBS school was $\$ 193,875,000$; however, the median generated revenue at the FBS level was $\$ 44,455,000$ (Fulks, 2015). At the FCS level, the largest generated revenue was $\$ 20,911,000$ in 2014; however, the median generated revenue at the FCS level was $\$ 4,137,000$ (Fulks, 2015). Despite the fact that FCS institutions do not have the financial resources of their FBS counterparts, FCS institutions are still multi-million-dollar entities.

\section{NFL draft demographic.}

From the data above, the difference between the two subdivisions may seem diminutive; however, FBS athletes have a far greater chance of entering into the National Football League draft due to the level of competition, exposures, and facilities provided by FBS institutions. According to the NCAA (2016a) in 2014, 255 NCAA football players were selected: Division I FBS (230), Division I FCS (19), Division II (6), and Division III (0). The top five conferences, or "Power Five", accounted for 172 of the 255 draft picks (South Eastern Conference=49, Atlantic Coast Conference=42, Pacific-12 Conference-12=34, Big Ten=30, Big 12=17) (NCAA, 2016a). The FCS only housed 7\% of the draft picks, just 5\% more than Division II (NCAA, 2016a).

\section{Student-Athlete Experience}


Although there are 489,003 NCAA student-athletes (Irick, 2015), little is known of the student-athlete experience. Most studies are quantitative in nature and focus on student-athletes in general and not on student-athletes competing at different NCAA Divisions. Student-athletes are a unique and special population (Gayles, 2009; Papanikolaou et al., 2003) because they are forced to choose between being a student and being an athlete (Yopyk \& Prentice, 2005). Additionally, due to the intensity of intercollegiate athletics, student-athletes are denied a well-rounded experience (Potuto \& O'Hanlon, 2007). Although student-athletes are deprived of the traditional college experience, some student-athletes report having a positive educational experience (Potuto \& O’Hanlon, 2007).

The NCAA limits Division I varsity teams to a maximum number of practice hours a week. For example, collegiate football teams are allowed to practice a maximum of 20 hours a week in season (maximum of four hours per day) (NCAA, n.d.). According to the NCAA's Countable Athletically Related Activities (CARA) document (NCAA, n.d.), the 20 hour cap does not include team meals, travel, banquets, community service or fundraising, voluntary weight training (no coach or staff member present), study hall, compliance, educational (drug/alcohol) and CHAMPS/Life Skills meetings, training room activities (e.g., treatment, taping, ice baths, rehabilitation, etc.), or recruiting activities (i.e., hosting a recruit). Student-athletes are expected to balance 20 hours a week of strict physically demanding activity, competition, and being a fulltime student with finding time to interact with others in social settings (NCAA, n.d.).

Some may consider the role as a collegiate student-athlete comparable to a full-time jobholder. Due to the mental, emotional, and physical demands, an athlete has to work hard to not identify solely as an athlete. Individuals who strongly invest in the role as an athlete are susceptible to difficulties regarding the transition into other social, educational, or vocational roles (Lavalle \& Wylleman, 2000). Individuals who fail to explore career, education, or lifestyle alternatives outside of the athlete role in which they identify experience identity foreclosure (Brewer, Van Raalte, \& Linder, 1993; Marcia, 1966; Petitpas, 1978). In the case of foreclosure, the athlete fails to explore any life options outside of their serious involvement in sport. To ensure student-athletes have a positive experience, further inquiry is warranted.

\section{Identity Development}

Self-identity is "comprised of those goals, values, and beliefs which the person finds personally expressive to which he or she is unequivocally committed" (Waterman, 1982, p. 6). The concept refers to how the individual defines him or herself. There lies the emphasis of a multidimensional view with the idea that self-identity and perceptions fluctuate according to the nature of the situational environment (Markus \& Wurf, 1987). For example, an individual may adjust the view of himself or herself depending on the domain in which is under consideration: social, academic, athletic, vocational, etc. More importance may be placed on the athletic role over social or academic identities during a competition season.

Brewer et al. (1993) introduced the concept of athletic-identity that is simply referred to as the extent to which an individual identifies with the athlete role. Houle, Brewer, and Kluck (2010) identified a tendency for athletes to experience external encouragement from coaches, parents, and schools to embed their identities in their athletic involvement (Kerr \& Dacyshyn, 2000; Klint \& 
Weiss, 1986; Krane, Greenleaf, \& Snow, 1997; Lavalle \& Robinson, 2007). Houle and colleagues also found that coaches reported to have rewarded athletes who were willing to strive above and beyond standards (Houle et al., 2010; Krane et al., 1997). The extent to which athletes are rewarded due to the amount of success they experience is one of many factors that influence how strongly the athlete identifies with the athletic role (Brewer et al., 1993; Houle et al., 2010).

Stephan and Brewer (2007) explored the social and personal issues that influence an athlete's athletic identity. Socially, collegiate athletes rarely hold jobs or participate in extracurricular activities in addition to the responsibilities they hold as student-athletes (Stephan \& Brewer, 2007). There is an unspoken expectation to limit their social networks to teammates or other student-athletes. Brewer et al. (1993) found that an individual's athletic identity is heightened when placed in an athletic environment or surrounded by sports as opposed to the immersion of an individual in a non-or anti-athletic environment or when they are among those who do not participate in sports. Coaches may also emphasize identifying as an athlete during competition season to stay focused and endorse the social perspective of the student-athlete identifying as such. Athletes often find meaning in life according to their successes and failures through sport. Success in athletics gives athletes an enhanced view of self. Social influences could cause a preservation of athletic identity (Stephan \& Brewer, 2007) wherein the athlete's social environment continues to emphasize the importance of their role in sport.

\section{Student-Athlete Stereotype}

Regardless of a student-athlete's degree of internalized athletic identity, many collegiate student-athletes are faced with being stereotyped. Though their degree of athletic identity is an internal experience, stereotypes are assumptions based on the athletic identity that others place on student-athletes. These negative perceptions may be generalized to student-athletes as an entire population. Whether the stereotype originates from professors, administrators, fans, or fellow students, an increase in negative stigma decreases academic motivation (Yopyk \& Prentice, 2005). Student-athletes, especially minority football players, fight against the "dumb jock" stereotype as soon as they set foot on campus (Preacco, 2009; Watt \& Moore, 2001). African American males face greater stigmas than any other racial group documented so far (McDonald, Keys, \& Balcazar, 2007; Stone, Harrison, \& Mottley, 2012). African American athletes believe they are negatively stereotyped by professors and classmates as "dumb jocks" (Edwards, 1984) more than Caucasian student-athletes. Martin, Harrison, Stone, and Lawrence (2010) found that professors and other students were more lenient and forgiving of Caucasian student-athletes regarding academic performance, or lack thereof, and absences due to competition travel than of the minority African American student-athletes. Results of the Harrison et al. (2014) study revealed several important themes to recognize: most of a football student-athlete's peers also participate in collegiate or competitive athletics, many of these men aim to be ballplayers, these athletes positively connect with the term "baller", and understand and recognize that others (i.e., professors, staff, classmates, other students, etc.) see them primarily as "ballers" or ballplayers. A "baller" is a high profile athlete normally recruited for and participating in revenue-producing sports (Harrison et al., 2010). The athletic stigma aimed towards student-athletes "makes a substantial contribution to [studentathlete's] academic underperformance" (Dee, 2014, p. 182). Since student-athlete stereotypes contribute to academic underperformance (Dee, 2014), the stigma may influence the social settings in which student-athletes choose to associate. 


\section{Social Support}

A student-athlete's verbal and physical contact with their family may be sparse throughout the four, five, or six years of the student-athlete's eligibility due to the time constraint placed on athletes in dedication to their sport and education (Siekanska, 2012; Thompson, 2010). Though the family or support system does not have the amount of contact that a high school athlete may have, the social support still proves to be a big part of the athlete's life. In a study focusing on family environment and the importance of family presence in a young athlete's life, Siekanska (2012) identified the following results: higher achieving athletes' parents are more involved than low achievers and family environment is the most pertinent aspect of an athlete's life as well as the "most important socio-environmental dimension" (p. 386). The relationships in an athlete's life serve as an incredible influence over their sense of identity, choices and preferences, and help shape who the individual becomes. Most humans are products of their environment, especially who and with what they surround themselves (Sinclair, 2012).

Thompson (2010) identified several types of support a student-athlete receives from family: emotional, informational, tangible assistance, task appreciation, and esteem support. Emotional support occurs during transition, agony, and defeat. Informational support comes in the form of advice and tangible assistance in the forms of money or concrete goods. Task appreciation may be the most tangible form of family support in which members attend sporting events. Esteem support is provided in reiteration of academic capability or discrediting any stereotypes the student-athlete may face. From a psychosocial well-being standpoint, it is important for individuals to receive all of the various types of social support. While student-athletes do not necessarily need to be receiving all of their social support from their family members, the family is an important provider of social support to students during college (Zimet, Dahlem, Zimet, \& Farley, 1988). College students with sufficient social support from family members and others have been more successful at overcoming adverse experiences (Morgan \& Giacobbi, 2006).

\section{Culture}

There is a significant amount of research published on the cultural implications of an African American football student-athlete experience such as mis-education of African American student-athletes (Harrison, Bimper, Smith, \& Logan, 2017), African American male studentathletes' experiences with racism and stereotyping on campus (Beamon, 2014), and African American student-athletes' experiences attending predominately White institutions (Rutledge, 2014). There have also been articles pertaining to African American student-athletes as the majority and Whites as the minority (Henry \& Closson, 2012) as well as opportunities and barriers for minority coaches in Division I-A football (Park, Tomasini, \& Shields, 2010). The field has yet to explore Cuban or Hispanic football student-athletes and their experiences as other minority groups in the Football Bowl Subdivision or the Football Championship Subdivision. Beamon (2012) noted that race plays a role in "career maturity, sport socialization, sports career aspirations, and student-athlete academic success, with African-Americans having a more difficult experience than whites" (p. 205). Though Beamon (2012) focused implicitly on an African American population, we cannot assume the implications of the African American minority group can be generalized to other minority groups in collegiate athletics. 


\section{Hispanic Students in Higher Education}

With increased high school graduation rates, the number of Hispanic students accepted by colleges has increased dramatically in recent years. However, how to develop a program to increase the retention of these students becomes one of many challenges since Miller and García (2004) indicated that Hispanic students in higher education had a higher attrition rate compared to Caucasians and Asian Americans. Meanwhile, Hispanic students obtaining their college degree had lower GPAs than Caucasian and Asian Americans (Miller \& Garcia, 2004). Previous scholars aiming to understand Hispanic students' experience in current higher education have studied lack of social support, ethnic identity, and sense of belonging. Gloria, Castellanos, Lopez, and Rosales (2005) found that university comfort was the biggest predictor of whether Hispanic students could complete their college degree. They indicated that increased sense of cultural congruity, decreased perceptions of barriers, and positive perception toward the institution were positively correlated with Hispanic students' retention. In addition, the majority of institutions have difficulties understanding the experiences of Hispanic students. As Torres (1999) noted, even though Hispanic students seem to have embraced American culture, they still face conflicts in educational environments. Without the assistance of Hispanic faculty and staff to serve as mentors and advisors, their experiences were hardly understood and solved. Moreover, the college environment has proven to impact students' sense of belonging (Johnson et al., 2007). Johnson and his colleagues found that Hispanic students perceived a lower sense of belonging in institutions than Caucasian students. They also found that having an interaction with diverse peers on campus has a direct impact on Hispanic students' sense of belonging. In another study conducted by Hurtado and Carter (1997), researchers found that Hispanic students' involvement with social community also related to their sense of belonging on campus. A sense of belonging is important for studentathletes' psychosocial well-being, as social connectedness has been found to reduce psychological distress and buffer against the effects of stress that college students often encounter (Baumeister \& Leary, 1995; DeFreese \& Smith, 2013).

According to KewalRamani (2007), 44\% of Hispanic males participated in interscholastic sport. Hispanic males during the 2008-09 school year accounted for $4.5 \%$ of student-athletes, which was a $4.2 \%$ increase from 1999 (Ruffins, 2010). Hispanics accounted for $15.8 \%$ of the US population in 2010. Latinos make up the majority of professional boxing, soccer, and baseball, yet college is not utilized as recruiting grounds for professional teams. The NCAA (2016b) reported that only $2.1 \%$ of football student-athletes are Hispanic/Latino. Demographics of NCAA member institutions do not reflect the growth of Hispanics in the US. Sport youth participation in 2015 consisted of 15\% male Hispanics (Diversity Demographics, 2016). From 2009 to 2013, there was only a slight increase in both male and female $12^{\text {th }}$ grade Hispanic participation in sport (47.8\% to 52.8\%) (Child Trends Data Bank, 2015).

\section{FCS Literature}

After an extensive search, very few studies exist that examine the FCS. No studies could be found that specifically addressed the experiences of FCS athletes. FCS literature included studies on electronic marketing (Cooper, 2010; Havard, Eddy, Reams, Stewart \& Admad, 2012), 
athletic department change (Peachey \& Bruening, 2012; Peachey, Bruening \& Burton, 2011), Academic Progress Rate (APR) scores (Chandler, 2014; Johnson, Pierce, Tracy, \& Ridley, 2015), winning success (Jones, 2013), attendance (Falls \& Natke, 2015) and NCAA reclassification (Chandler, 2014; Dwyer, Eddy, Havard, \& Braa, 2010; Upright, 2009).

There have been a number of studies that have examined the business side of FCS sports. For example, Cooper's (2010) study examined electronic branding initiatives at NCAA Division I institutions (both BCS and FBS). The study found that FCS institutions had smaller marketing budgets and marketing staffs compared to FBS institutions. Furthermore, FCS institutions were found to be "reliant on microblogging sites such as Twitter to communicate with consumers" (Cooper, 2010, p. 30). A study by Havard et al. (2012) examined FCS student-athletes' and nonathletes' online social networking usage. Johnson et al. (2015) studied APR scores at FCS institutions and noted that APR scores (i.e., a student-athlete's retention and eligibility) were significantly lower after a coaching change, but increased with winning percentage. Peachey and Bruening (2012) examined the driving forces behind change within FCS athletic departments. It was found that alumni, parents, fans, budget concerns, and competitiveness within the athletic conference were catalysts (Peachey \& Bruening, 2012). Peachey et al. (2011) investigated the influence of leadership style on organizational change at one FCS institution. The findings indicated that transformational leadership and communication eased overall resistance (Peachey et al., 2011). Jones' (2013) study revealed that there was not a correlation between athletic spending and winning success at the FCS level. Higher ticket prices, high travel cost, and weather are negatively correlated with attendance at FCS football games (Falls \& Natke, 2015). However, the date the game was played on, team opponent (i.e., rivalry, conference opponent, or FBS opponent) and team performance was shown to increase attendance (Falls \& Natke, 2015). Last, research regarding the FCS has focused on reclassification from NCAA Division II to the FCS level (Dwyer et al., 2010) and from the FCS level to the FBS level (Upright, 2009). Furthermore, Chandler (2014) found that institutions that were reclassified had lower academic success rates when compared to other Division I intuitions. Thus, there is a huge gap in the literature regarding the 126 FCS institutions and the 12,948 student-athletes that participate in FCS football (Irick, 2015). This study sought to provide some insight into the lived experience of one of the thousands of student-athletes competing at the FCS level. The purpose of this study was to understand the embodied experience of a Cuban FCS football student-athlete. Therefore, the question guiding the study was: What is the nature of a Cuban student-athlete's experience participating in FCS football?

\section{Methods}

Throughout the following sections, the participant will be referred to as "He". Narrative was selected as the methodology because "narrative research is best for capturing the detailed stories or life experiences of a single life" (Creswell, 2007, p. 55). After all, "stories reveal truth about the human experience" (Riessman, 2008, p. 10). We are interested in the experiences of a single participant. Therefore, narrative is the appropriate methodology because it allows the participant's story to speak for itself (Riessman, 2008). Furthermore, "as a method, it begins with the experiences as expressed in lived and told stories" (Creswell, 2007, p. 54). Utilizing narrative methodology allows the audience to connect with the investigator (Riessman, 2008). Most importantly, narrative research can "mobilize others into action for progressive social change" 
(Riessman, 2008, p. 9). Due to the nature of narrative inquiry of humans as "storytelling organisms who, individually and socially, lead stories lives" (Connelly \& Clandinin, 1990, p. 2), we felt approaching this study through a theoretical lens would do the participant's story a disservice due to his unique position as a Cuban football student-athlete at a FCS institution. Although we understand that a case study might fit with this research and a case study can be done using just one participant, in many cases it is a methodology used to study "small groups" (Yin, 2009, p. 4). Furthermore, case studies are often used to study a social phenomenon (Yin, 2009). Although we feel this study is unique (as there is very limited research on the FCS as well as Cuban studentathletes) we do not feel this is a phenomenon as much as it is an understudied population.

A very significant student-athlete on the football team was the focus of this narrative. This particular student-athlete was asked to participate because he was a senior and a member of $0.7 \%$ of football student-athletes at the FCS level that are Hispanic/Latino. This student-athlete had also excelled in his sport and was not only named the Male Student-Athlete of the year for his athletic conference, but was also a finalist for the Walter Payton Award.

This study was approved by the university's IRB board and the participant was given the opportunity to ask questions prior to signing the informed consent and collecting any data. Interviews were chosen as a method of investigation because interviews "attempt to understand the world from the subjects' point of view, to unfold the meaning of their experiences, and to uncover their lived world prior to scientific explanation" (Kvale \& Brinkmann, 2009, p. 1). Semistructured interviews are "more or less open-ended questions brought to the interview situation in the form of an interview guide" (Flick, 1998, p. 94). He participated in one interview that lasted 52 minutes during the end of football season.

Along with interviewing, document analysis was used to validate this study. According to Creswell (2007) "journaling is a popular data collection process in case studies and narrative research" (p. 131). Therefore, He was asked to journal bi-weekly about his academic encounters throughout the semester. Upon the completion of this study, the participant provided us with 12 journal entries that spanned eight weeks. By examining the participant's journal entries, we were given more insight into what He was experiencing outside of our interactions.

\section{Data Analysis}

After reading through the interview transcripts and journal entries multiple times to become familiar with the data, the researchers used open coding to label and separate the themes that emerged from the data according to Creswell (2007). Open coding allows the researcher to first place the information into categories with similar features, then gradually reduce the categories into major themes with maximum variation between themes and minimum variation within themes (Creswell, 2007). The use of open coding assists the researcher in identifying unexpected themes and allows the themes to emerge from the data, rather than attempting to fit the data into an existing theoretical structure (Merriam, 2009).

\section{Trustworthiness}


Trustworthiness was established though triangulation (i.e., methods, peer review, member checking) (Denzin, 1978; Patton, 1999). Specifically, triangulation was achieved by collecting data through different methods, allowing different aspects of the phenomenon to be examined (Denzin, 1978; Patton, 1999). Along with interviewing, document analysis was also utilized. Trustworthiness was also established through peer review. Other qualitative researchers reviewed our work and provided us with constructive feedback. The participant also took part in member checking. He was sent a transcript of specific questions that we believed needed clarification. We then asked him to read over the transcript to ensure that he truly conveyed through his interview what he wanted to articulate.

\section{Results}

Following the completion of the data analysis, four main themes emerged as prominent in the collegiate student-athlete experience for the participant: football, identity, social support, and stereotype. These four themes significantly influenced His overall experience as a stand-out football student-athlete at a FCS institution. He spoke and wrote often of His dedication to the sport of football and the extent to which His life revolved around the sport. He also often discussed his overall identity, athletic identity, and cultural identity. The social support He received from His family and community played a large role in His college experience as well. Finally, He spoke of being stereotyped as a "dumb jock" because of his cultural background.

\section{Football}

"I don't even know what kind of structure my life would have if I didn't have football," He stated. Throughout his journals and his interview, there is continuous mention of football. Overall, it appeared that football played a significant role in his life. He said it best: "football season is just so much more important than anything else right now."

Most of He's journals involved the subject of football. He used journaling not only to help him envision what He wanted to happen before each game, but also as a reflection exercise of what happed after every game. In his first journal entry, He shared his anticipation for the season opener.

Sitting on the flight to [destination], the whole team is excited to play! After coming off a bad loss last year to [opponent] we are better stronger and faster and we are ready to take on the defending [conference] champs! They are a solid team. We need to execute and we will be fine.

Throughout his journals, He shared his feelings of playing football and how important winning was to him. He valued competition and enjoyed playing the game. He wrote about how he was out for revenge over the opponents that defeated him last year: "REVENGE is the only thing I can think about. Last year we lost to this team in double OT, which made our season end early due to not getting a higher bid in the playoffs. We're coming for redemption." He later wrote,

This team is usually the worst team in the conference so we plan on having a stat day. We will hopefully light up the scoreboard and get our 2's some game experience. Last time I 
played @ [opponent] they flooded the guest locker room with poop water from the drainage pipes so maybe I'll be able to take revenge this weekend.

In his journals, He wrote about his "huge" games, and the "excitement and fun" he experienced from scoring touchdowns. He also spoke about his leadership skills throughout his interview, "I definitely feel like I'm one of the captains on the team and one of the motivational leaders," he stated. "It's camaraderie with your people, just like practicing every day, and then going out there and working as a team." He valued his individual success, but often referenced his team.

I did exactly what we thought scored 63 points! I had 5 catches and 3 TDs which is a pretty good percentage! Again good team win just a speed bump to the [conference] championship. After this game we have been ranked top 5 in the country feels good to be recognized and have the no1 offense in the nation!

Although the "offense was clicking like crazy," He wrote words of disappointment regarding losses: "Real pissed off at how the game ended," he wrote, "Lost by 4 to a very good FBS team. If we had won it would've have def made noise across the country! We had a huge lead and let them come back." He constantly spoke to his dedication to football, "I can't even imagine not watching football games on Sunday." Overall, He's dedication to football, specifically athletic ability, leadership, and team value was shown throughout the data.

\section{Identity}

He also discussed identity in terms of overall identity, athletic identity, and cultural identity. Overall, He stated he was an "interactive learner," and a "hard worker was the kinda the person [he wants to] be." Throughout the data, it was clear that sport was internalized in He's life: "I've been doing sports since I was six and every year I had never stopped or had a year off, that's pretty much all I know." He described himself as "super competitive," explaining that He's "always wanted to be the best at everything." He talked about high school, explaining that He was a good student; however, when he got to college, "classes got boring" and football became his priority. He felt he was "more of an athlete than a student." When He was asked if he was a student or an athlete, he responded:

Uhm I mean, I would want to say student-athlete 'cause I'm a part of the NCAA and that's what we are, but I'm definitely more of an athlete than a student I would say. I used to be way more of a student than an athlete in high school, I was actually a very good student. I had a 3.5 GPA in a top 50 Catholic high school. Ugh I got an 1180 on my SAT. So ya know I was pretty smart, I just kinda...the college scene came and school just wasn't important anymore.

Athletic participation played a huge configuration in He's life: "I don't even know what kind of structure my life would have if I didn't have football". He stated "I'm basically who I am because of athletics." Such thought was also consistent throughout He's journals, which comprised of only the topic of football and its importance, as stated in the first theme.

Throughout our conversation, He explained to us the importance of his Cuban family. He wrote about how excited he was that his family had traveled so far to watch his game: "it's nice to 
have my family in the stands." He self-identified as Cuban and discussed his cultural identity briefly: "I was a short, white-Hispanic that is not very common in football." However, although He is Cuban, He told us "in the category thing I mark Hispanic." Although he felt "you still need to take pride from where you come from," He explained that due to the lack of understanding in regards to the Cuban population in certain parts of the country, he referred to himself as Hispanic because his peers simply "don't understand." Although He's athletic identity appeared to be prominent, it is important to consider his overall cultural experience as well. After all, He himself classified his identity as a "multiple-sided polygon."

\section{Social Support}

He described his family a lot throughout his interviews and journals. He's mom was a cheerleading coach and his dad was a football coach, thus, his parents had a huge influence regarding He's decision to pursue athletics.

Well especially my mom and dad, they, ya know ever since I was a little kid, every Saturday was sports day, they'd take me to the park. And I mean my mom, was a cheerleading coach over there, my dad did the football coach, I would go there at 9 in the morning, play my game and stay there til 10 o'clock at night. Hanging out at the park with all my friends, playing sports, playing "kill the man with the ball" after games, I mean it was just, my whole life it's always been ya know Monday through Friday practice, Saturday game day, do it for every sport, I mean it went football, soccer, basketball, baseball and just year round like that. So I mean they've always been around. Uh my brother was a high school football player so I always kinda looked up to that, uhm unfortunately he didn't finish high school sooo ya know he stopped playing football. Uhm, I mean other than that, I mean my aunts have always supported me, everyone's always been pretty pro athletics so.

He seemed ecstatic when speaking of his family and friends. He was so proud that they were coming to support him by attending his games: "my dad's making the trip," "plus my fam is going as well!" and "my friends are coming into town to celebrate."

Aside from support from He's family and friends, He mentioned the impact his community had on his life.

When I first left for school, uh it was pretty much my mom and dad only, ya know nobody else really followed me, and then about the last year and a half ago when I started gettin kinda good, ya know, I started getting some more social love between everybody. I mean, that happens, ya know it's not, it's not anything new to me, but you definitely see the difference.

He's success on the field earned him All-American status and He became a celebrity over night. "Uhm I turned into an All-American. The year before I sat out because of an injury so it kinda went from not playing to All-American status pretty fast. So, that was the big uh 'Oh' everyone's your fan now." He also mentioned the fans/crowd and support outside of football personnel (including the institution and surrounding community), $\mathrm{He}$ "had a pretty big crowd" and 
"started getting more social love between everybody". He's tone almost questioned the authenticity of the "love" he received after earning All-American honors.

\section{Stereotype}

In our conversation, He explained to us that He had felt stereotyped: "I don't like ceilings, I don't like society or people or anybody putting a ceiling on someone." One cultural stereotype in particular was prevalent during his in-season experience and shone through in the following quotes: "if you're Hispanic you're Mexican or Puerto Rican" and "people always called me Mexican and at first it bothered me."

Along with feeling culturally stereotyped, He spoke of feeling stereotyped as a studentathlete. He believed many considered him to be "arrogant and an asshole because I'm an athlete." He further stated, "before I was just another kid who didn't like to do work and now I'm the AllAmerican football player who doesn't want to do anything," "they just thought of you as a studentathlete who didn't care", and "they perceive athletes as you know, dumb jocks or people who don't care or sports first." He goes on to provide us with an example of how He was stereotyped in the classroom.

Last year uh I had a teacher, honestly, I don't even remember their name. But uh, uhm I, I didn't go to class on, specifically on Thursdays because last year we did the same thing, we had 6am practice on Thursdays and I just really did not like to go to class after that practice. And so I just didn't. And she didn't have an attendance policy, ya know, and she didn't say it was bad and so I didn't go. I still passed the class and then at the end of the semester, she had told me, 'Oh you had this many absence, I'm gonna have to lower your grade, you're gonna have to retake my class.' And I asked her and I was like, 'Oh but I thought there was no absences' and she was like, 'Yeah well mid semester I changed the syllabus and made absences count. And you had 7, so therefore after 3 you lose a grade,' so I had a B in the class. I had to retake the class because of the absences. And whether or not it was because I was an athlete or not, I think she generalized like I wasn't giving a crap because I was an athlete. And she brought up the point of football player, football player, football player. So I, ya know, I don't think it was mainly 'cause of football but I think that had something to do with, ya know, having so much strict policy on me and what I was doing. That's a big thing with me is missing class.

Overall, it was clear that He experienced several different instances of stereotype due to both his culture and his status as an athlete.

Table 1

Findings Matrix of Quotes and Themes

\begin{tabular}{lll}
\hline $\begin{array}{l}\text { Representative Verbatim Quotes From } \\
\text { Transcribed Data }\end{array}$ & Axial Codes & $\begin{array}{l}\text { Open } \\
\text { Codes }\end{array}$ \\
\hline "I couldn't even imagine not watching football & & \\
games on Sunday" & Dedication to football & Football
\end{tabular}


"football season is just so much more important than anything else right now"

"went from not playing to All-American status pretty fast"

"I wasn't the fastest guy"

"we pulled out a double OT win"

"one of my quietest games but feels good to get quality wins"

"It's wake up at 6am, go to practice 6:20-7:45. 8 am we have practice, we get out, I eat breakfast go to class at 9.9 to $10: 15$ I go to class, I have a 45 minutes break. From 11 to 12:15 I have class again, then I get a break. I go home, eat lunch, have like 30 minutes to hangout. 1:45 I go to the stadium, do treatment for 30 minutes. 2:30 we start meetings. We have meetings from 2:30 to 4:30. They let us out and then at 6 we gotta come back and workout from 6 to 7:30. I have treatment again, my last treatment of the day, ice my legs, go home, and I don't get home til 8:15-8:30. And that's every Thursday"

"follow team rules and lead by example more than anything"

"I definitely feel like I'm one of the captains of the team and one of the motivational leaders"

"I had a couple other offers to other schools"

"there will be a lot of people watching and more interesting scouts!"

"the camaraderie with your people, just like practicing every day, and then going out there and working as a team"

“we trust each other and we really let each other's roles play out"

"I'm a hard worker, I'm an old school football player, and that's kinda the person I wanna be" "I don't want to have one side, I'd like to be a multiple side polygon"

"I'm an interactive learner"

"I'm basically who I am because of athletics" "I'm definitely more of an athlete than a student I would say"

"I don't even know what kind of structure my life would have if I didn't have football"
Athletic Ability

Competition/Games

Routine

Leadership

Scholarship Offers

NFL Association

Football Personnel 
"I am Cuban but in the category thing I mark

Hispanic"

Cultural Identity

"I was short, a White-Hispanic that is not very common in football"

"in Miami I call myself white down there 'cause everyone's kinda like that"

"I think you still need to have pride in where you're from"

Social

"my dad's making the trip"

Family

Support

"plus my fam is going as well!"

"my friends are coming into town to celebrate

homecoming and its gonna be one hell of a weekend"

Friends

"spent a great weekend with my friends"

"spent hanging out at the park with all my friends"

"had a pretty big crowd"

Fans

"it was our first game in front of the home crowd, it was very energetic and fun!"

"I started getting more social love between

everybody"

Non-football support

"You definitely see the difference"

"oh, everyone's your fan now"

"if you're Hispanic you're Mexican or Puerto

Rican"

Cultural Stereotype Stereotype

"I'm not making fun of them, it's just they're not aware of the Cuban culture"

"And uh, so that was definitely a difference when I came up here. You know, people always called me Mexican and at first it bothered me"

"probably arrogant and an asshole because I'm an athlete"

Student-Athlete Stereotype

"before I was just another kid who didn't like to do work and now I'm the All-American football player who doesn't wanna do anything"

"it changes people's opinions about me"

"they just thought of you as a student-athlete who didn't care"

"they perceive athletes as you know, dumb jocks or people who don't care or sports first"

"generalize athletes"

"I don't like ceilings, like I don't like society or people or anybody putting a ceiling on someone" 
"I just hate being confined"

\section{Discussion}

Research on the Football Championship Subdivision is limited and only a scant amount of literature has touched on marketing (Cooper, 2010; Havard et al., 2012), departmental change (Peachey \& Bruening, 2011; Peachey, Bruening, \& Barton, 2011), APR scores (Chandler, 2014; Johnson et al., 2015), winning percentages (Jones, 2013), attendance (Falls \& Natke, 2015), and reclassification (Chandler, 2014; Dwyer et al., 2010; Upright, 2009). Research on Cuban studentathletes is also limited and scarce. The Center for Education Statistics predicts that the Hispanic population in higher education will reach $42 \%$ by 2021 (Hussar \& Bailey, 2013), which could possibly affect intercollegiate football demographics. For an individual who identifies as Cuban but also Hispanic when identifying on demographic questions, this population is an important one to explore.

The nature of He's descriptions of his marriage to football as his number one priority indicates the deprivation of a well-rounded experience, consistent with Potuto and O'Hanlon (2007). Student-athletes have a more positive collegiate experience when they are invested in other activities and groups beyond just their sport. He also invested an incredible amount of time and energy into his identity as an athlete, which affected his role as a college student, consistent with Lavalle and Wylleman's (2000) research on student-athletes' difficulties transitioning into other roles. Due to his All-American status, the community surrounded him with support and encouraged him to continue to perform on the field, which is consistent with findings that the environment can often promote immersing oneself in his or her athlete role (Kerr \& Dacyshyn, 2000; Klint \& Weiss, 1986; Krane et al., 1997; Lavalle \& Robinson, 2007). Negative effects such as declined commitment and performance in the classroom (Stephan \& Brewer, 2007) and more difficult transitions out of sport can often result from a student-athlete possessing a high athletic identity.

He felt he experienced negative student-athlete stereotypes in the classroom when professors assumed He was academically unmotivated and uninterested in learning, which is consistent with the literature (Yopyk \& Prentice, 2005). Also consistent was the fight against the "dumb jock" stereotype as a minority student-athlete (Preacco, 2009; Watt \& Moore, 2001; Winninger \& White, 2008). From the interview transcriptions and journal entries, it is possible He was treated more unfairly due to his student-athlete status. However, He admitted to contributing minimal effort into his education (Dee, 2014), so while He may have been treated unfairly by some of his professors, on the other hand, some of He's experience could be attributed to his lack of effort into He's courses. However, He did express a passion to learn outside of the classroom. Some of He's interests included science, TED talks regarding science, and the intricacies of the game of football and how difficult it is to learn. Studying plays, counts, signals, etc. requires skills and tools learned in an academic setting to understand, retain, and perform on the field of play. Student-athlete stereotypes may influence academic motivation but in this particular case, the student-athlete was still motivated to learn more on his own about the subjects in which he was interested.

A student-athlete may find stress in life events such as transition, agony and defeat, attending a predominantly white institution as a minority, managing basic responsibilities, money, 
stereotype (athletic and cultural), as well as producing (i.e., winning) on the field and in the classroom (Thompson, 2010). Social support can serve to buffer student-athletes from some of the stress they face (Baumeister \& Leary, 1995; DeFreese \& Smith, 2013). He mentioned family and friends coming to support him through task appreciation and attending games: "my dad's making the trip," "plus my fam is going as well!" and "my friends are coming into town to celebrate." Also mentioned were fans/crowd and support outside of football personnel including the institution and surrounding community as He "had a pretty big crowd" and "started getting more social love between everybody." He did discuss an increase in social support, but seemed to question the authenticity of the "love" he received, given so much of it came after He earned All-American honors.

\section{Limitations}

This study has several limitations. First, the participant was a student in two of the researchers' classes. Thus, He could have felt obligated to participate in this study. In addition, another researcher coding the transcribed interview and documented journals was a student-athlete and positionality may have influenced bias in coding. Third, He was simply asked to journal about his feelings when he felt compelled, given little direction in regards to completing his journals. Although the researchers believed that vague directions would allow us to see what he was thinking about, it may have been more helpful if the researchers provided the participant with clarifying instructions and structure in regards to He's journals. This study is not generalizable to the studentathlete population; rather, this study looked at the experience of one student-athlete.

\section{Conclusion}

This study offers a number of contributions to sport literature. It is one of the first to explore the experience of a FCS football student-athlete. Most of the literature to date focuses on Division I football student-athletes encompassing both FCS and FBS or researching FBS institutions specifically. In contrast to the minority literature in collegiate football that focuses specifically on African American student-athletes (i.e., Beamon, 2012; Henry \& Closson, 2012; Park et al., 2010), this study also sheds light on a Cuban or Hispanic football student-athlete's experience. Predicted growth of the Hispanic population in higher education is $42 \%$ by the year 2021 (Hussar \& Bailey, 2013). This does not indicate that there will be a $42 \%$ increase of the Hispanic population in intercollegiate football, but could still potentially impact the ethnic demographic of NCAA Division I football.

\section{Implications and Future Research}

There are several practical implications for this study. First, it is important for practitioners to understand that the intersectionality of student-athletes' lived experiences and identities is complex. As such, it is important that student-athletes are provided with opportunities outside of athletics to grow and develop as well as cultivate a deeper understanding of their selves. Given the much smaller percentage of FCS student-athletes that advance to a higher level of play (e.g., NFL) when compared to FBS student-athletes, an emphasis on psychosocial development appears to be far more necessary for FCS student-athletes. Furthermore, oftentimes student-athletes that are in 
the limelight are seen to be incapable and unwilling to learn, as demonstrated with the studentathlete stereotype prevalent in this study. Every student is a part of the campus community and as such it should be inferred that every student is in college to learn. Perhaps investing more time in relationship building between the student-athletes and faculty or other community members can combat some of the challenges and stereotypes student-athletes, especially minorities, face on the college campus. Finally, given that He used the term "multiple-sided polygon" to classify his ethnic and cultural identity, it's possible more research on athletes with similar backgrounds may uncover that they do not consider themselves to fit solely into one ethnic demographic. Additional research on underrepresented populations in collegiate sport could lead to clear and effective strategies that professors, coaches, advisors, and others could use to enhance the student-athlete experience in these populations.

This study should not be generalized; after all, this narrative looks at the experience of one unique individual. However, the exploration of one Cuban FCS football player also has practical implications for those working in, participating in, or in contact with intercollegiate athletics. Division I institutions, athletic departments, and the NCAA need to explore FCS student-athletes' experiences separate from FBS athletes. In addition to exploring experiences, all involved in intercollegiate athletics need to gain a better understanding of the student-athletes' own perception of the stereotypes against them and how that impacts academic and athletic performance. Finally, if there is a significant increase in the Hispanic population in five to six years, institutions need to implement programs that will make Hispanics and Cuban individuals identifying as Hispanic feel more included in the athletic department and institution.

In the future, scholars should continue to study Hispanic student-athletes to better understand the experiences of this population in collegiate sport. Previous research has found that a variety of variables (e.g., gender, race and ethnicity, social class, sport type, support for academic success) have a large effect on the meanings college student-athletes give to their college sport experience (Coakley, 2017). Better understanding of the experiences of student-athletes in this under-researched population could provide coaches and other practitioners concrete strategies to use to better enhance the student-athlete experience.

Future research should also look at other minority student-athlete populations (i.e., African American, Asian, international) to better understand the needs of such populations. The examination and comparison of FCS and FBS student-athletes' experiences may shed light on differences and similarities in student-athlete experience within the two subdivisions. Furthermore, more qualitative inquiry is needed in collegiate sport. Oftentimes, research consists of statistical analysis, but qualitative research allows us to truly understand the lived experiences of individuals and groups. Qualitative research allows us to truly hear the words of the participants.

Finally, the definition of social support system may be unique to a student-athlete due to the exposure and contact with several support systems. The social support system may include friends, family, teammates, fans, community, and others. However, an athlete may separate his or her social support systems into one system containing all individuals with an association to their sport, and another system containing everyone else. Therefore, additional research is needed to examine the unique culture of participating in Football Championship Subdivision as a studentathlete. Doing so could result in information that coaches, professors, and other practitioners 
working with student-athletes could utilize to better enhance the student-athlete experience at FCS institutions.

\section{References}

Baumeister, R. F., \& Leary, M. R. (1995). The need to belong: Desire for interpersonal attachments as a function of fundamental human emotion. Psychological Bulletin, 112, 461-484.

Beamon, K. (2012). 'I'm a Baller': Athletic identity foreclosure among African-American former student-athletes. Journal of African American Studies, 16(2), 195-208. 
Beamon, K. (2014). Racism and stereotyping on campus: Experiences of African American male student-athletes. The Journal of Negro Education, 83(2), 121-134. doi:10.7709/jnegroeducation.83.2.0121

Brewer, B. W., Van Raalte, J. L., \& Linder, D. E. (1993). Athletic identity: Hercules' muscles or Achilles heel? International Journal of Sport Psychology, 24, 237-254.

Chandler, J. I. (2014). The impact of NCAA reclassification on academic success rates. (Doctoral dissertation). Retrieved from ProQuest Dissertations \& Thesis database. (3580927)

Child Trends Data Bank. (2015). Participation in school athletics: Indicators of child and youth well-being. Child Trends. Retrieved from: https://www.childtrends.org/wpcontent/uploads/2015/10/37_Participation_School_Athletics.pdf

Coakley, J. (2017). Sports in society: Issues and controversies (12 ${ }^{\text {th }}$ ed). New York, NY: McGraw Hill.

Connelly, F. M., \& Clandinin, D. J. (1990). Stories of experience and narrative inquiry. Educational researcher, 19(5), 2-14.

Cooper, C. G. (2010). New media marketing: The innovative use of technology in NCAA athletic department E-branding initiatives. Journal of Marketing Development and Competitiveness, 5(1), 23.

Creswell, J. W. (2007). Qualitative inquiry and research design: Choosing among five approaches $\left(2^{\text {nd }}\right.$ ed.). Thousand Oaks, CA: Sage Publications.

Crowley, J. N. (2006). In the arena: The NCAA's first century. Indianapolis, IN: National Collegiate Athletic Association.

Dee, T. S. (2014). Stereotype threat and the student-athlete. Economic Inquiry, 52(1), 173-182.

DeFreese, J. D., \& Smith, A. L. (2013). Teammate social support, burnout, and self-determined motivation in collegiate athletes. Psychology of Sport and Exercise, 14(2), 258-265.

Denzin, N. K. (1978). Sociological methods. New York, NY: McGraw-Hill.

Diversity demographics of American youth sports. (2016, February 23). Ohio University. Retrieved from: http://onlinemasters.ohio.edu/diversity-demographics-of-americanyouth-sports/.

Dwyer, B., Eddy, T., Havard, C., \& Braa, L. (2010). Stakeholder perceptions of an athletic program's reclassification from NCAA division II to NCAA division I (FCS) membership: A case study. Journal of Intercollegiate Sport, 3, 76-97.

Edwards, H. (1984). The "Black dumb jock": An American sports tragedy. The College Board Review, 131, 8-13. 
Falls, G. A., \& Natke, P. A. (2015). College football attendance: A panel study of the football championship subdivision: Attendance in college football championship subdivision. Managerial and Decision Economics, n/a. doi:10.1002/mde.2740

Flick, U. (1998). An introduction to qualitative research. Thousand Oaks, CA: Sage.

Fulks, D. (2015). Revenues \& expenses: NCAA division I intercollegiate athletics programs report. Indianapolis, IN: NCAA. Retrieved from http://www.ncaa.org/sites/default/files/2015\%20Division\%201\%20RE\%20report.pdf

Gayles, J. G. (2009). The student athlete experience. New Directions for Institutional Research, 2009(144), 33-41.

Gloria, A. M., Castellanos, J., Lopez, A. G., \& Rosales, R. (2005). An examination of academic nonpersistence decisions of Latino undergraduates. Hispanic Journal of Behavioral Sciences, 27(2), 202-223.

Harrison, C., Rasmussen, J., Connolly, M., Janson, N., Bukstein, S., \& Parks, C. (2010). Diggin’ deeper into the culture of revenue sports: The need for the Baller Identity Measurement Scale (BIMS) in assessing academic and athletic identities in society. Journal for the Study of Sports and Athletes in Education, 4(3), 325-332.

Harrison, C., Tranyowicz, L., Bukstein, S., McPherson-Botts, G., \& Lawrence, S. (2014). I am what I am? The baller identity measurement scale (BIMS) with a division I football team in American higher education. Sport Sciences for Health, 10(1), 53-58.

Harrison Jr., L., Bimper Jr., A. Y., Smith, M. P., \& Logan, A. D. (2017). The Mis-Education of the African American Student-Athlete. Kinesiology Review, 6(1), 60-69.

Havard, C. T., Eddy, T., Reams, L., Stewart, R. L., \& Ahmad, T. (2012). Perceptions and general knowledge of online social networking activity of university student-athletes and nonstudent-athletes. Journal of Applied Sport Management, 4(1).

Henry, W. J., \& Closson, R. B. (2012). The racial identity development of male student-athletes when blacks are the majority and whites are the minority. Journal of Student Affairs Research and Practice, 49(1), 17-32.

Houle, J. W., Brewer, B. W., \& Kluck, A. S. (2010). Developmental trends in athletic identity: A two-part retrospective study. Journal of Sport Behavior, 33(2), 146-159.

Hurtado, S., \& Carter, D. F. (1997). Effects of college transition and perceptions of the campus racial climate on Latino college students' sense of belonging. Sociology of Education, 70(4), 324-345. 
Hussar, W., \& Bailey, T. (2013). Projections of education statistics to 2021. National Center for Education Statistics, 40, 1-161.

Irick, E. (2014). Student-athlete participation 1981-82-2013-14: NCAA Sports Sponsorship and Participation Rates Report. Indianapolis, IN: NCAA.

Irick, E. (2015). Student-athlete participation 1981-82-2014-15: NCAA Sports Sponsorship and Participation Rates Report. Indianapolis, IN: NCAA.

Johnson, D. R., Soldner, M., Leonard, J. B., Alvarez, P., Inkelas, K. K., Rowan-Kenyon, H., \& Rowan-Kenyon, H. (2007). Examining sense of belonging among first year undergraduates from different racial/ethnic groups. Journal of College Student Development, 48(5), 525-542.

Johnson, J. E., Pierce, D. A., Tracy, D. R., \& Ridley, M. J. (2015). The influence of football head coaching change in the football championship subdivision: An evaluation of the NCAA academic progress rate. Journal of Sport Behavior, 38(1), 26-26.

Jones, W. (2013). Exploring the relationship between intercollegiate athletic expenditures and team on-field success among NCAA division I institutions. Journal of Sports Economics, 14(6), 584-605.

Kerr, G., \& Dacyshyn, A. (2000). The retirement experience of elite, female gymnasts. Journal of Applied Sport Psychology, 12, 115-133.

KewalRamani, A. (2007). Status and trends in the education of racial and ethnic minorities. National Center for Education Statistics. Retrieved from http://files.eric.ed.gov/fulltext/ED498259.pdf

Klint, K. A., \& Weiss, M. R. (1986). Dropping in and dropping out: Participation motives of current and former youth gymnasts. Canadian Journal of Applied Sport Science, 11, 106114.

Krane, V., Greenleaf, C. A., \& Snow, J. (1997). Reaching for gold and the price of glory: A motivational case study of an elite gymnast. The Sport Psychologist, 11, 53-71.

Kvale, S., \& Brinkmann, S. (2009). Interviews: Learning the craft of qualitative research interviewing ( $2^{\text {nd }}$ ed.). Thousand Oaks, CA: Sage.

Lavallee, D., \& Robinson, H. K. (2007). In pursuit of an identity: A qualitative exploration of retirement from women's artistic gymnastics. Psychology of Sport \& Exercise, 8, 119141.

Lavallee, D., \& Wylleman, P. (2000). Career transition in sport: International perspectives. Morgantown, WV: Sheridan Books. 
Marcia, J. E. (1966). Development and validation of ego-identity status. Journal of Personality and Social Psychology, 3, 551-558.

Markus, H., \& Wurf, E. (1987). The dynamic self-concept. Journal of Personality and Social Psychology, 38, 299-337.

Martin, B., Harrison, C., Stone, J., \& Lawrence, S. (2010). Athletic voices and academic victories: African American male student-athlete experiences in the Pac-ten. Journal of Sport \& Social Issues, 34(2), 131-153.

McDonald, K. E., Keys, C. B., \& Balcazar, F. E. (2007). Disability, race/ethnicity and gender: Themes of cultural oppression, acts of individual resistance. American Journal of Community Psychology, 39(1), 145-161.

Merriam, S. B. (2009). Qualitative research: A guide to design and implementation. San Francisco, CA: Jossey-Bass.

Miller, L. S., \& García, E. E. (2004). Better informing efforts to increase Latino student success in higher education. Education and Urban Society, 36(2), 189-204.

Morgan, T. K., \& Giacobbi, P. R. (2006). Toward two grounded theories of the talent development and social support process of highly successful collegiate athletes. The Sport Psychologist, 20, 295-313.

National Collegiate Athletic Association (2014a). Football bowl subdivision--membership requirements. Indianapolis, IN: NCAA.

National Collegiate Athletic Association. (2014b). NCAA Division I manual. Indianapolis, IN: NCAA.

National Collegiate Athletic Association (2016a). Estimated probability of competing in professional athletics. . Indianapolis, IN: NCAA. Retrieved fromhttp://www.ncaa.org/about/resources/research/estimated-probability-competingprofessional-athletics

National Collegiate Athletic Association (2016b). Sports sponsorship, participation and demographics. Indianapolis, IN: NCAA. Retrieved from http://web1.ncaa.org/rgdSearch/exec/main

National Collegiate Athletic Association (n.d). Countable athletically related activities. Indianapolis, IN: NCAA. Retrieved from https://www.ncaa.org/sites/default/files/20Hour-Rule-Document.pdf

Papanikolaou, Z., Nikolaidis, D., Patsiaouras, A., \& Alexopoulos, P. (2003). The freshman experience: High stress--low grades. Athletic Insight, 5(4). 
Park, S. R., Tomasini, N., \& Shields, J. W. (2010). Perceived opportunities and barriers to employment in the football coaching profession differences between NCAA division I-A African-American and Caucasian football student-athletes. International Journal of Applied Sports Sciences, 22(1), 33-58.

Patton, M. Q. (1999) Enhancing the quality and credibility of qualitative analysis. Health Services Research 34(5), 1189-1208.

Peachey, J., \& Bruening, J. (2012). Investigating ambivalence towards organizational change in a football championship subdivision intercollegiate athletic department. Sport Management Review, 15(2), 171-186.

Peachey, J. W., Bruening, J., \& Burton, L. (2011). Transformational leadership of change: Success through valuing relationships in a football championship subdivision athletic department. Journal of Contemporary Athletics, 5(2), 127.

Petitpas, A. J. (1978). Identity foreclosure: A unique challenge. Personnel and Guidance Journal, 56, 558-561.

Potuto, J. R., \& O'Hanlon, J. (2007). National study of student-athletes regarding their experiences as college students. College Student Journal, 41(4), 947.

Preacco, L. (2009). Student-athlete worldview: A qualitative discovery of student -athletes' outlook of the world through their athletic experiences.

Riessman, C. K. (2008). Narrative methods for the human sciences. Thousand Oaks, CA: Sage Publications.

Ruffins, P. (2010, October 5). Game delay: Latinos not yet scoring with college athletics. Diverse Issues in Higher Education. Retrieved from http://diverseeducation.com/article/14216/

Rutledge, M. E., II. (2014). African American student athletes at predominately white institutions and motivational factors that influence graduate and professional degrees. Retrieved from OAK Trust Digital Repository.

Siekanska, M. (2012). Athletes' perception of parental support and its influence on sports accomplishments -- a retrospective study. Human Movement, 13(4), 380-387.

Sinclair, B. (2012). The social citizen: Peer networks and political behavior. Chicago, IL: The University of Chicago Press.

Stephan, S. \& Brewer, B. W. (2007). Perceived determinants of identification with athlete role among elite competitors. Journal of Applied Sport Psychology, 19, 67-79. 
Stone, J., Harrison, C. K., \& Mottley, J. (2012). "Don't Call Me a Student-Athlete": The effect of identity priming on stereotype threat for academically engaged African American college athletes. Basic \& Applied Social Psychology, 34(2), 99-106.

Thompson, J. (2010). Social support and minority student-athletes. Journal of Issues in Intercollegiate Athletics, 2010(3), 234-252.

Torres, V. (1999). Validation of a bicultural orientation model for Hispanic college students. Journal of College Student Development, 40(3), 285-298.

Upright, P. A. (2009). Reclassification to the NCAA division I football bowl subdivision: A case study at western Kentucky university. Louisville, KY: University of Louisville.

Waterman, A. S. (1982). Identity development from adolescence to adulthood: An extension of theory and review of research. Developmental Psychology, 18, 341-358.

Watt, S. K., \& Moore, J. L. (2001). Who are student athletes? New Directions for Student Services, 2001(93), 7-18.

Winninger, S., \& White, T. (2008). The dumb jock stereotype: To what extent do studentathletes feel the stereotype? Journal for the Study of Sports and Athletes in Education, 2(2).

Yin R. K. (2009). Case study research: Design and methods (4th ed.). Thousand Oaks, CA: Sage.

Yopyk, D., \& Prentice, D. (2005). Am I an athlete or a student? Identity salience and stereotype threat in student-athletes. Basic and Applied Social Psychology, 27(4), 329-336.

Zimet, G. D., Dahlem, N. W., Zimet, S. G., \& Farley, G. K. (1988). The multidimensional scale of perceived social support. Journal of Personality Assessment, 52(1), 30-41. 